
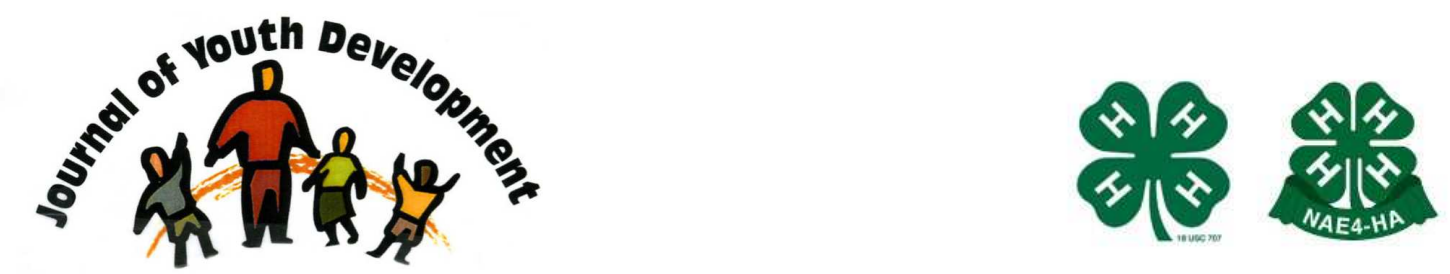

Bridging Research \& Practice

\title{
Local Food: Does It Matter What You Eat?
}

\author{
Brian Raison \\ Ohio State University Extension \\ Troy, $\mathrm{OH}$ \\ raison.1@osu.edu
}




\title{
JOURNAL OF YOUTH DEVELOPMENT \\ bridging research and practice

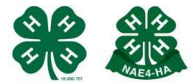

Volume 5, Number 2, Summer 2010

Article 100502RR001

\section{Local Food: Does It Matter What You Eat?}

\author{
Brian Raison \\ Ohio State University Extension
}

\begin{abstract}
Everybody eats. Period. Some of us prefer hamburgers. Some like veggies. But what we eat is only the beginning. Increasingly, interest in where our foods are grown and processed has emerged. As numerous grass roots organizations proffer information on local foods, it becomes critical for research-based youth programs to also encourage study on this topic. This article introduces a new curriculum that aims to help students learn about what we eat, where it comes from, and how it impacts the environment. The main goal is to help participants understand the concept of local food systems, how they operate, and how students and their families can be involved in creating positive changes. It targets students in grade school thru high school. By stimulating their interest at an early age, we can encourage their participation in the local food systems movement. The curriculum is available as a self-study guide at no cost. Email: raison.1@osu.edu.
\end{abstract}

\section{Introduction}

Everybody eats. Period. Some of us prefer hamburgers. Some like veggies. Almost all like to choose items from the "Cake Food Group." (Okay. That's not really in the food pyramid.) But what we eat is only the beginning. Increasingly, the interest in where our foods are grown and processed has emerged. As numerous grass roots organizations proffer information on local foods, it becomes critical for research-based youth programs to encourage study on this topic.

The goal of this new curriculum is to help students learn about what we eat, where it comes from, and how it impacts the environment. Participants will learn about the concept of local food systems, how they operate, and how students and their families can be involved in creating positive changes. The saying says, "You are what you eat." And if that's true, this program will challenge students to begin thinking about eating in a manner that positively affects their family, school, community, country, and world. 
The curriculum is set up as a program guide that introduces activities to engage students in a wide age range from grade school thru high school. Again, with the dramatic increase in the interest and activity of local foods programming, it becomes critical to engage a student audience. Stimulating their interest at an early age will encourage their participation in the future.

\section{The Approach}

The program guide begins by asking students to think more critically about food: Does it matter where your food comes from? Is there any difference between tomatoes grown locally vs. those that arrive on a truck from 1,500 miles away? What does chemical ripening of fruits and vegetables mean? Is that safe? Can what you eat really impact the environment . . . positively or negatively?

\section{Why Local Food?}

The curriculum introduces students to the dramatic increase in the amount of news reports on local foods. It discusses how more and more people are planting gardens or making a point to buy their food from a farmer in their local community. Locally grown food is healthier, fresher, cleaner, and better tasting... and it keeps the money in the local economy (Fisher, 2006; Thomson, 2006; Timmons, Wang and Lass, 2008; UMD 2010).

Here is an excerpt of the "Why Local Foods" segment. It provides an idea of the approach and tone of the curriculum.

Let's begin with the news reports. Along with the local foods interests, other stories detail all kinds of food recalls. It seems that every month you hear about another batch of contaminated food along with warnings about eating it. Killer peanut butter. Killer spinach. Killer dog food. What's next? Is some contaminated item already in your freezer? Help!

Clearly, the big question for students is this: Can we do anything to ensure a safe and nutritious food supply? The short answer is yes. Let's begin with a discussion of the concepts of basic supply and demand economics and how they might influence the local foods markets.

Reasons to buy locally grown and produced foods are also discussed. For example, the Rural Life Center at Kenyon College in Gambier, Ohio produced a brief fact sheet providing some key points.

1. Freshness. Local fruits and vegetables are usually harvested and sold more quickly so they do not contain the preservatives that are added to products shipped long distances and placed in storage.

2. Taste. Produce that is ripened on the vine has better texture and flavor than produce harvested unripe, then treated with chemicals and ripened during shipping.

3. Nutrition. Nutritional value declines—often drastically—as time passes after harvesting. 
4. Improving the local economy. When you buy homegrown food, you circulate your food dollars inside the local area.

5. Strengthening producer/consumer relations. When purchasing food locally, consumers can ask how the product was grown and processed, what chemicals if any were used, and any other questions they may have. People tend to trust individuals they know.

\section{Economic and environmental considerations}

Students will be introduced to the basic concepts of food miles. On average, most food travels over 1,500 miles before it reaches our plates (Hill, 2008; Pirog, 2003). That distance obviously has a negative impact on the environment. Transportation vehicles (trucks, trains, airplanes) burn fossil fuels that pollute the environment. But students must also consider economies of scale that exist in the trucking and shipping industry. We give an example of one large truck that carries 50,000 pounds of tomatoes may cause less pollution than 50 smaller trucks carrying 1,000 pounds each. Finally, we ask if students would rather help create and maintain foodrelated jobs in their local community or send dollars out of state?

\section{Food systems and policies}

The curriculum briefly introduces local food systems. the often complex network of food producers (farmers), food consumers (eaters), and the businesses that link them together. Some refer to this as the food chain. Generally speaking, there are five main links in the food system chain:

\section{Production 2. Distribution 3. Processing 4. Consumption 5. Waste recovery}

But a local food system does more than just connect growers, businesses, and consumers in a region. It considers the bigger issues of health and nutrition, economic development, environmental sustainability, and overall community strength. Together, these elements greatly impact how people in a community live and interact. Increasingly, these elements are governed by food policies.

A food policy consists of the rules and regulations that govern how food is produced and distributed. These are generally run by a Food Policy Council whose primary goal is to cultivate a stronger and more sustainable local food system in order to bring benefits to residents of a region.

Activities and things to do:

Here are samples of the activities that students may do to complete the project curriculum. These vary in complexity and may be given as optional assignments, depending on their age category.

\section{Food at Your House: What's in your refrigerator?}

- Meal Planning: incorporate at least 2 locally grown or produced foods into your family meals each week for one month. (Next month, try for three or four!)

- Family Food Survey: Review your family's food shopping habits.

1. Make a list of the stores where your family usually buys their food. 
2. Are the stores owned locally or are they regional/national chains?

3. Why does your family choose to shop there?

4. Does your family ever shop at farmer's markets?

5. If not, what would make them stop and shop there?

6. Are you concerned with food safety? List 4 things that might cause concerns.

7. Are you aware of the food eco-footprint? List 4 ways that food production and distribution might negatively impact the environment.

- Start a compost bin in your kitchen. Keep it clean and fresh by emptying it every few days into a compost pile outside.

\section{Food at Your School: What are they serving?}

- Ask your school cafeteria director if they serve any local foods. Dig deep. Ask why or why not?

- Do a quick Internet search on "local food in schools" and write a short essay (2 or 3 paragraphs) describing your findings. Could your school participate? What foods would be easy to begin with?

- Organize a campaign to ask your school to offer fruit that is grown locally. Include vending machines!

\section{Food in Your Community: Where can you buy local foods?}

- Ask your supermarket produce manager if they purchase foods that are grown or produced locally. Dig deep. Ask for their definition of "local." Do they consider it within a 50-mile radius?

- Investigate restaurants in your town that serve locally grown or produced foods. The next time your family eats out, ask to go to one of them. (And remember to tell the restaurant why you chose them!)

- Investigate farmers markets in your area. How many are there? What days / hours do they operate? What types of foods and products do they sell?

- CSA Sign-Up: Go online and search for any Community Supported Agriculture (CSA) or Food Co-Op operating in your area. Investigate the pricing structure. Compare it to supermarket expenses. Discuss with your family the benefits of fresh food, and think about signing up.

- Do a report for your class or club on what you've discovered under this "Food in Your Community" topic. 
Food in Your World: Where does it come from? Is there a balance between local and far?

- Conduct a food-origins survey: Go to any grocery store, look at the fruit, and make a list of all the countries (non-U.S.) the fruit comes from. Which is furthest away? Which is closest? What one surprised you most? Is there one you've never heard of?

- Do a quick Internet search on "fair trade" foods. Is this labeling system helpful to people in other countries? Do you think it helps the environment? Write a short essay ( 2 or 3 paragraphs) on why or why not.

- Write a short essay (2 or 3 paragraphs) on why it's okay to purchase and eat foods that are from far away. Think about health benefits (e.g., eating citrus that is rich with Vitamin C during cold and flu season). Does health outweigh the transportation issue?

\section{Conducting the program:}

The Local Foods Idea Starter curriculum was blind peer reviewed at Ohio State and then shared with colleagues at the National Association of Community Development Extension Professionals (NACDEP) national meeting in Minneapolis in April, 2010. Educators at the West Virginia State University Extension service are already planning to incorporate the curriculum into their Jr. Master Gardener outreach and teach it with their 4-H programming. Feedback is still limited, but initial reports from students have been quite positive.

Youth development educators may contact Brian Raison [raison.1@osu.edu] for a free electronic copy of the curriculum. It is designed to be used with a self-determined project outline such as the OSU Self-Determined 4-H Project Starter Guide (also available as a free download).

\section{References}

Fisher, S. (2006). Local-grown food tastier, healthier, speakers say. The Advance, Volume 24, No. 32. University of Connecticut. Available at:

http://advance.uconn.edu/2006/060530/06053014.htm

Hill, H. (2008). Food Miles: Background and Marketing. National Sustainable Agriculture Information Service (ATTRA), National Center for Appropriate Technology (NCAT) and the United States Department of Agriculture's Rural Business-Cooperative. Available at http://attra.ncat.org/attra-pub/PDF/foodmiles.pdf

Lipstreu, A. (2007). The Ohio Food Policy Council. Ohio Department of Agriculture. Retreived June 21, 2010 from http://www.agri.ohio.gov/divs/FoodCouncil/foodcouncil.aspx\#FPC

Pirog, R. (2003). Checking the food odometer: Comparing food miles for local versus conventional produce sales to Iowa institutions. Leopold Center for Sustainable Agriculture, Iowa State University Ames, Iowa. Available at:

http://www.leopold.iastate.edu/pubs/staff/files/food travel072103.pdf 
Thomson, J.S. (2006). Strengthening Community Engagement Toward Sustainable Local Food Systems. Journal of Extension [On-line], 44(4). Available at: http://www.joe.org/joe/2006august/a2.php

Timmons, D., Wang, Q., Lass, D. (2008). Local Foods: Estimating Capacity. Journal of Extension [On-line], 46(5). Available at: http://www.joe.org/joe/2008october/a7.php

University of Maryland (UMD) Extension. (nd). FCS Tips \& Information: 10 Reasons to Eat Local Food. Retreived June 21, 2010 from http://frederick.umd.edu/FamilyConsumerScience/FCS\%20Tips\%20\%20\%20Info.cfm

(C) Copyright of Journal of Youth Development $~$ Bridging Research and Practice. Content may not be copied or emailed to multiple sites or posted to a listserv without copyright holder's express written permission. However, users may print, download or email articles for individual use. 